\title{
An Investigation of the Benefits and Challenges of Graduation Internship Perceived by Students of English Language Studies
}

Tran Ngoc Tien

Hoa Sen University, Viet Nam

tien.tranngoc@hoasen.edu.vn

Vu Thi Quynh Trang

University of Huddersfield, Huddersfield, United Kingdom

u2051897@unimail.hud.ac.uk

DOI: http://doi.org/ 10.36892/ijlls.v2i4.455

\begin{tabular}{|c|c|}
\hline $\begin{array}{l}\text { Received: } \\
\text { 29/11/2020 }\end{array}$ & $\begin{array}{l}\text { Abstract } \\
\text { Graduation internship has been proved to play a vital role in students, }\end{array}$ \\
\hline $\begin{array}{l}\text { Accepted: } \\
\text { 15/12/2020 }\end{array}$ & $\begin{array}{l}\text { personal and professional development. It can also be considered a } \\
\text { preparatory step for students to gain practical knowledge and supervised } \\
\text { experience. However, what students encounter and how students value the } \\
\text { internship are still debatable. This study explores how students of English }\end{array}$ \\
\hline $\begin{array}{l}\text { Keywords: } \\
\text { graduation } \\
\text { internship; } \\
\text { internship benefits; } \\
\text { internship } \\
\text { challenges; } \\
\text { employability; } \\
\text { personal and } \\
\text { professional skills. }\end{array}$ & $\begin{array}{l}\text { Language Studies at Hoa Sen University, Vietnam, perceive the benefits and } \\
\text { challenges of their graduation internship through a mixed-method study on } 92 \\
\text { undergraduate students via survey questionnaires and in-depth interviews. } \\
\text { The study employed descriptive data analysis and multiple regression to } \\
\text { analyze quantitative data and grounded theory techniques for qualitative } \\
\text { information. The findings show that students value graduation internship as } \\
\text { an opportunity to enhance their personal skills and employability. The study } \\
\text { also finds out that the difficulties students face when performing given } \\
\text { professional tasks are insufficient personal skills and lack of professional } \\
\text { knowledge. Additionally, results from multiple regression analysis reveal that } \\
\text { understanding job values and confirming career aspirations have a positive } \\
\text { correlation with perceived internship necessity while building future career } \\
\text { plans and expanding working relationships have negative directions. The } \\
\text { research findings can be of value for the higher educational institutions in } \\
\text { adjusting or redesigning their programs to meet the demand of the workforce. }\end{array}$ \\
\hline
\end{tabular}

1. INTRODUCTION

Graduation internship, according to Patton and Dial (1988), is a form of workingbased learning in which students gain practical knowledge and supervised experience. Graduation internship has been considered as a crucial component of an academic curriculum in higher educational institutions (Coco, 2000; Cook, Parker \& Pettijohn, 2004; Gault, Redington \& Schlager, 2000; Stichman \& Farkas, 2005). The earliest internship was recorded to occur in the Accounting Department at the University of Cincinnati in 1906 (Thiel \& Hartley, 1997). Although expanding from cooperative education, internship possesses four main different characteristics. These include 1) students work as part-time employees; 2) salary is not obligatory; 3) school credits are provided for interns; and 4) both universities and industries function as the interns' mentors (Coco, 2000; DiLorenzo-Aiss \& Mathisen, 1996; Divine, Linrud, Miller \& Wilson, 2007; Maelah, Mohamed, Raml \& Aman, 2014).

Taylor (1988) believed that the nature and operation time of the internship needed to be well structured and relevant to students' majors. Additionally, students should take an internship prior to their graduation. Hoyle and Deschaine (2016) emphasized the role of supervision by indicating that internship is the opportunity to learn and comprehend practical expertise embedded in industrial and social organizations under the support of academia. 
Brooks and Simpson (2014), upon examining 205 students and alumni having joined internship, concluded that experiential learning is beneficial for students' personal growth, professional growth, and employment gain. These findings are in agreement with a longitudinal study conducted by Cook, Parker and Pettijohn (2004) on 351 interns from 12 institutions. In their study, Cook, Parker and Pettijohn found that internship brings an encouraging learning experience for the interns and optimistic results for the businesses and higher education institutions.

Despite having been implemented in academia for a long time, the internship program is still a controversial issue concerning the recognition of its value for the interns and the operators (Moran, 2013). In Vietnamese context, since the Decree No. 102-TTg of the Vietnamese Prime Minister concerning internship was issued in 1962, there has been an increasing trend in internship implementation. However, Vietnamese students are still believed to be in compelling need of soft skills to maximize their success in labour market (Vo, Berglund \& Daniels, 2017). They were also found not to have a positive attitude towards improving their soft skills at the workplace (Truong, Laura \& Shaw, 2016). This causes interns more challenges when entering the real workforce (Tran, 2019) and makes the research on their perceptions of the graduation internship highly significant.

This study aims to explore the effectiveness of the graduation internship. More specifically, this study examines the benefits gained and the challenges encountered by the students majoring in English Language Studies at Hoa Sen University, Vietnam, in their graduation internship. The study also attempts to investigate the level of internship necessity perceived by the interns and looks for the factors contributing to the perception of the interns that internship is crucial to their self-development. To achieve the aims, the study employed a mixed methods approach. Data was collected through survey questionnaires on 92 respondents, and in-depth interviews with 22 participants. Some additional informal dialogues were also used to confirm the research findings. SPSS programme was employed for descriptive and multiple regression analysis and Grounded theory techniques suggested by Glaser and Strauss (2009) were used for qualitative data analysis.

This study can have several significances. It can help to understand what students desire to achieve in their future careers. Students have the opportunities to confirm their career aspirations and build their skillset such as communication, problem-solving, adaptability, and teamwork, etc. needed for working culture. For universities, this is a chance to evaluate to what extent their students can apply knowledge learnt at school in professional culture. Universities can use practical experience in the internship to boost their students' learning. For students majoring in English language studies, internship is a chance to improve their language proficiency through authentic comprehension and effective use. For these reasons, a study focusing on the perceptions of the English-majored interns in their graduation internship is highly significant.

\section{CONCEPTUAL BACKGROUND}

\section{Benefits of Graduation Internship}

Numerous studies have been conducted and claimed that internship can provide students with opportunities to combine professional education with practical experience (Degravel, 2011; Moghaddam, 2011; Nevett, 1985; Renganathan, Karim, \& Li, 2011). Internship is incorporated into the school curriculum based on the premise that students' learning happens more effectively when they are immersed into professional culture (Degravel, 2011; Yassin, Abdul Razak, Qasem, \& Saeed, 2020). Thiel and Hartley (1997) argued that internship yields greater meaning when attached to the school curriculum. The merit of education, according to Henry, Razzouk and Hoverland (1988) is boosted when students are provided with practical experience. 
Additionally, internship experience is supposed to enhance and consolidate personal skills and knowledge (Bradshaw, Tighe \& Doody, 2018). These involve awareness of the interns' thoughts, feelings, and ego to act with mindfulness and understanding (Ryff \& Singer, 1996). These are the skillset that one needs in order to accomplish the requirements, both in job and in life. Furthermore, personal skills affect students' ability for lifelong learning (Brooks \& Simpson, 2014). Via internship, an individual can gain various skills such as communication, problem-solving, adaptability, and teamwork (Bradshaw, Tighe \& Doody, 2018; Cook, Parker \& Pettijohn, 2004).

Internship is also considered a chance for the interns to become more mature (Anjum, 2020 ) in both actions and thinking (Cook, Parker \& Pettijohn, 2004). This is because when in need of resolving an issue, an individual would thoughtfully consider aspects of results (Cook, Parker \& Pettijohn, 2004). Through internship, interns could improve their critical thinking (Duncan, Birdsong, Fuhrman \& Borron, 2017) and communication skills (Ahanchian, Sharafi, Vafaee \& Hajiabadi, 2017). Problem-solving skill, which refers to the ability to make appropriate decisions in order to control the situation when facing a problem, has a close link to the employability of the employee in the 21 st Century (De Fruyt, Wille \& John, 2015) can be gained through the internship time together with independent working and report writing (Scholz, Steiner \& Hansmann, 2004). Besides, interns are more adaptable when getting used to new working environments (Jackling \& Natoli, 2015). Last but not least, collaboration is achieved when interns use self-regulatory ability so as to work together with their peers and develop better ideas (Golinkoff \& Hirsk-Pasek, 2016).

Interns also gain a competitive edge when searching for a job. Via internship, students could navigate their future career plans (He \& Qin, 2017) by changing or confirming career aspirations (Novotorov, 2001); and enhance their competitiveness when attending job markets (Jackling \& Natoli, 2015). Furthermore, they could be retained to work full-time for their internship companies if having good performance (Scott, 1992). A quantitative research by Gault, Redington and Schlager (2000) showed that those who graduated with internship program in their academic curriculum obtained first jobs faster than non-interns (1.98 months and 4.34 months respectively) and had higher starting salary as well as job satisfaction than the non-interns (Gault, Redington \& Schlager, 2000).

Internship experience, from the students' perspectives, is significant for the following reasons. It is necessary for consolidating professional skills, confirming career paths, and building positive learning attitudes (Tran \& Duyen, 2018). Berryman (1991) purported that much of the learning that takes place in the classroom is ineffective. From Berryman's study, two of the wrong assumptions about learning were (1) learners are passive knowledge receivers and (2) knowledge and skills are independently acquired from the context of use (Berryman, 1991). A study conducted by Nicholas (2016) indicated the need for students to become actively involved in learning and the need for educators to create real learning contexts for students. Practical and vivid experiences that students are exposed to could help them engage more in learning, as well as retain the knowledge in memory for a longer time frame (Santrock, 2011). Furthermore, internship enhances students' career preparation. Ross and Elechi (2006) investigated criminal justice's students' attitudes towards internship experiences and concluded that students see internship as an invaluable aspect in preparing them for their future careers.

\section{Challenges of Graduation Internship}

Besides benefits gained, challenges are also a part of the internship experience. Some of the difficulties were believed to come from the interns themselves because of inadequate preparation (Spann, 1994). Spann (1994) also indicated that this is due to the lack of initial planning of the interns for the ways they would execute the internship. Firstly, the students may not be well academically prepared to attend the program. Jackling and Natoli (2015) surveyed 11 internship providers exploring the employability of the international accounting 
graduates in Australia. They concluded that the foreign accounting interns lacked English language proficiency, which caused challenges when they communicated and executed tasks. Doing the internship is not an individual-working experience since the interns work in a real workplace, communicate with probable-future colleagues, and are assigned real tasks involving teamwork. Therefore, the experiential process could only make learning meaningful when students acquire both job's professional knowledge and personal skills prior to their internship period (Akella, 2010).

Another factor leading to the poor performance of the students during the internship is inflexibility. Inflexible employees are those who are unwilling to make changes (Leeder, 2007). As an intern, an inflexible personality may result in unproductive working performance and poor communication (Ip, 2015). Degravel (2011), on the other hand, found out that interns are not passive recipients in the internship, instead, they are active to make sure their internship goals and job objectives match the host companies. Degravel (2011) believed that interns should consider themselves having two roles at the same time, trainees and real workers. Interns should not only regard themselves as temporary workers. This would make them afraid to state their opinions and not be able to pay attention to their tasks.

Inadequate preparation and unclear guidance from schools and inappropriate supervision from host organizations could also cause a disappointing internship. With regard to universities, internship arrangements and academic preparation are the two primary obstacles that students face. In terms of arrangement, pre-placement operation, postplacement examination, and guidance of the internship coordinator play important roles. Renganathan, Karim and Li (2011) collected and analyzed data from nearly 250 interns who had completed their eight-month internship and concluded that around $40 \%$ of students rated the effectiveness of pre-placement operations "neutral" or "bad". The studies of Thiel and Hartley (1997), and Renganathan, Karim and Li (2011) claimed that universities do not provide students with sufficient orientation sessions. Thus, their growth is less likely to occur when there is an imbalance between facilitators and barriers (Jackel, 2011).

A nationwide study of Stichman and Farkas (2005), reviewing 99 internship programs, concluded that there is a need for the universities to review every company periodically and observe students in the workplace. Additionally, the availability of the program coordinators is a concerning factor in guiding and evaluating interns' experiential learning process since learning could not happen fully without experts' guidance (Kolb, 1984). The guidance needs to be intensive and frequent. In relation to the knowledge that students learn in the classroom, Renganathan, Karim and Li (2011) emphasized the negative correlation between theories taught in the university and practical tasks assigned at the workplace.

Students might also have problems with their supervisors, the tasks assigned, and their intern status (Hoover, O'She \& Carroll, 1988). Scott (1992) interviewed an associate director of career planning and placement at the University of Michigan about the internship. The director emphasized the important role of company supervisors after realizing that supervisors are not willing to do their supervision tasks or are not prepared to do the tasks. The lack of qualified staff to supervise interns is mainly attributed to their busy schedule, short supply, and insufficient pedagogical knowledge (Gault, Redington, \& Schlager, 2000). Scott's research (1992) also urged for the need of providing interns with major-related tasks. Novices may not professionally develop if the number of students' majored tasks are tremendously lower than those of the menial tasks. Another research conducted by Jackling and Natoli (2015), however, pointed out the need for such menial or peripheral tasks because through peripheral tasks, novices generally have a sense of belonging to the community. Furthermore, some interns have a sense of injustice since they report that companies view them as disposable labour (Ip, 2015) and treat them with very basic employee rights (Kasli \& Ilban, 2013). 


\section{METHODOLOGY}

\section{Research Approaches}

This study used a mixed-methods approach supported by survey questionnaires, indepth interviews, observations and informal dialogues. This combination of qualitative and quantitative approaches can produce many advantages (Lodico, Spaulding \& Voegtle, 2006). It helps to explore a research issue both in-depth and width, both causative and meaning, and allows both to test and develop a hypothesis (Cresswell, 2012). Besides, qualitative approaches can be used to gain subjective viewpoints of the research participants and explore a deep understanding of the phenomenon (Cohen, Manion \& Morrison, 2002) while quantitative method can investigate a research phenomenon in width, evaluate variables, test hypotheses and calculate the prevalence of the research results (Muijs, 2010). To be more specific, this study employed combined methodology since it can reach a considerable number of students and alumni within a short period of time. Besides, by observing and interacting with the interviewees, researchers can have insights on the reasons why the respondents regard the given elements positively or negatively (Bryman, 2012).

\section{Research Instruments}

The construction of the questionnaire followed six vital steps suggested by Dörnyei and Csizér (2012). First, general features and questionnaire length were decided. From the literature review, four main sections were agreed upon including demographic information, internship benefits, internship difficulties, and an open-ended question section. Afterwards, the questionnaire length was examined. Since participants were interns and alumni, both electronic version and hardcopy version were delivered to maximize the accessibility. The second step was drawing an item pool for each main part based on the theoretical background. The next step was gathering selected items from the pool. The items selected needed to connect with the main research topic and the section direction. In the fourth step, the items were paraphrased and worded so as to make the ideas clear and concise. The questionnaire was then translated to the target language of the respondents, Vietnamese, for more accurate and faster reading comprehension. In the final step, the questionnaire was discussed with a couple of potential research participants and experts for checking the questionnaire validity, and then the piloting stage was conducted with two groups of interns. The final instrument was completed with three parts and 37 items.

The questionnaire was then checked validity by discussions with four lecturers of the Faculty of Foreign Languages and a group of six students who were taking the graduation internship. This process aimed to assure the questions reflected the real meaning of the concepts (Babbie, 2014) and appeared understandable (Gifford, 2012). The comments mainly concerned the wording of a couple of items that should be short and clear. For instance, keywords should be highlighted and a unified form of sentences should be used. Before being officially delivered, the questionnaire and interviewed questions were reviewed, finalized and gone through a pilot testing phase with 4 respondents similar to the research participants to make sure that the questionnaire causes no confusion in terms of content and wording.

\section{Data Collection and Analysis Procedures}

Survey questionnaires were delivered to respondents via emails and in person from March to April 2018. A total of 95 undergraduate students and alumni participated in the survey. The students were from four concentrations of the English Study major. These included Business English, Translation and Interpretation, Corporate Communication, and English Language Teaching. After data was collected, a computer-assisted program called Statistical Package for Social Science (SPSS) version 20 was used to analyze quantitative 
data. Initially, outliners were checked to guarantee no extreme outliners influenced the outcomes of the study (Pallant, 2013). A total of 92 questionnaires were finally used for data analysis. Then, a descriptive phase was conducted to preliminarily analyse data to look for factors of benefit and difficulty perceived by the research participants. Standard multiple regression was used to explore the correlation between variables of internship benefits and the internship necessity perceived by the research participants. Multiple regression was also employed to check how well items of internship benefits could significantly predict participants' perception of the internship necessity.

During the time of quantitative data collection, in-depth interviews, group discussions and informal dialogues were conducted to look for the respondents' perception of internship benefits together with their responses to the difficulties they encountered. Interviewees were encouraged to express their opinions and feelings about the issues. Concurrently, non-verbal language was observed during the interviews to confirm the reliability of the conversations. After sending invitations to collaborate in the study through emails and text messages, twenty-two undergraduate students and alumni from all concentrations agreed on taking part in the interviews and discussions. As the interview began, the conversations were recorded via both field-notes and an audio recorder with the consent of the informants. Qualitative data collected from interviews was analysed using Grounded theory techniques guided by Glaser and Strauss (2009). Data transcription of each interview was gathered and broken into items and then thoroughly studied, compared, and classified under categories formed from both literature review and the resemblance of the items. Items in each category were used for data analysis on condition that they were related to the research phenomena.

\section{FINDINGS AND DISCUSSION}

\section{Benefits of Graduation Internship Perceived by Students Majored in English Studies}

\section{Table 1. Benefits of the Graduation Internship Perceived by Students Majored in English Studies}

\begin{tabular}{|c|c|c|c|c|c|}
\hline \multirow[t]{2}{*}{ No. } & $\begin{array}{l}\text { Benefits of the Graduation Internship } \\
\text { (5-point Likert-type scales) }\end{array}$ & \multirow{2}{*}{$\begin{array}{l}\text { Mean } \\
(\mathrm{n}=92)\end{array}$} & \multirow{2}{*}{$\underset{\mathrm{m}}{\operatorname{Minimu}}$} & \multirow{2}{*}{$\underset{\mathrm{m}}{\text { Maximu }}$} & \multirow[t]{2}{*}{ Std. Dev } \\
\hline & The internship is beneficial to me because I (can): & & & & \\
\hline 1 & become more adaptable to different circumstances. & 4.41 & 3 & 5 & .517 \\
\hline 2 & become more mature in terms of personality. & 4.35 & 2 & 5 & .670 \\
\hline 3 & enhance my employability skills. & 4.33 & 2 & 5 & .713 \\
\hline 4 & enhance my communication skills. & 4.29 & 3 & 5 & .603 \\
\hline 5 & enhance my problem-solving skills. & 4.23 & 3 & 5 & .648 \\
\hline 6 & expand my working relationship. & 4.22 & 1 & 5 & .810 \\
\hline 7 & know how to perform vital tasks in the working position. & 4.17 & 1 & 5 & .735 \\
\hline 8 & enhance my skills in computer and office facility usage. & 4.14 & 1 & 5 & .735 \\
\hline 9 & build my future career plans. & 4.13 & 2 & 5 & .683 \\
\hline 10 & understand job values. & 4.13 & 1 & 5 & .633 \\
\hline 11 & enhance my English language proficiency. & 4.10 & 2 & 5 & .757 \\
\hline 12 & expand my professional knowledge. & 4.09 & 2 & 5 & .736 \\
\hline 13 & confirm my career aspirations and career goals. & 3.98 & 2 & 5 & .741 \\
\hline 14 & enhance my team work skills. & 3.91 & 2 & 5 & .721 \\
\hline 15 & apply academic knowledge on experiential learning. & 3.87 & 2 & 5 & .759 \\
\hline Over & 11 mean & 4.15 & & & 697 \\
\hline
\end{tabular}


Table 1 shows the mean scores for the 15 items of internship benefits perceived by students majored in English language studies at Hoa Sen University, Vietnam. Using a fivepoint Likert-type scale, the mean score ranged from "Strongly disagree" (1) to "Strongly agree" (5) with number 3 representing "Neither disagree nor agree". Generally, most students agreed that the graduation internship was beneficial with the mean score standing at 4.15. Findings revealed that the most beneficial aspects of the internship were enhancing students' adaptability, personal growth and employability. This finding was in line with that of Cannon and Arnold (1998); and Jianning and Lee (2019) whose respondents viewed internship as a tool to gain competitive edge in the marketplace rather than a means of augmenting professional knowledge. Similar students' expectations were found in Cook, Parker and Pettijohn's longitudinal study (2004), whose results showed that the largest benefits perceived by students are social or personal values. Students' perspective is also in agreement with employers' perspective, who expect employees to have a high level of soft skills rather than hard skills (Pennington, 2013). Additionally, qualitative data collected from the interviews indicated that through internship, interns had a chance to execute real tasks, which minimally related to knowledge learnt at school. Executing such tasks was mentioned to help interns enhance soft skills or interpersonal skills needed to perform on the tasks smoothly. By self-observing, interns made a progress in communication ability and adaptability skills.

Although the internship is valued as a central element of experiential learning (Kuh, 2008; Sides \& Mrvica, 2007), its goal of securing employment has been proved to be one of the crucial benefits. Internships provide students with the opportunities to be trained, and recruited informally (Hergert, 2009; Scott, 1992). The research participants emphasized the importance of finding a job after graduation - the job is a way for them to not only earn money but also define themselves. The internship is seen as a means for novices to know or discover the most appropriate career path for their lives. Particularly, the non-experiential students largely benefit from the valuable chance that the internship offers.

In contrast, professional knowledge development was viewed as not very beneficial by the interns in the study. This might be because students gain enough theoretical knowledge in their curricula. Those of the lowest mean scores are "Apply academic knowledge on experiential learning" and "Confirm my career aspirations and career goals". These items belong to the professional growth category. From the interviews, the informants revealed that these were due to shortage of time and heavy tasks assigned. Firstly, within the period of 15 weeks, it was hard for students to see a significant improvement in their professional knowledge. One more reason was that some interns comment on the heavy workload received in a short period of time. Thus, the quantity of their work largely counterinfluenced the quality of the production. This means students do not have enough time to supply their technical knowledge.

\section{Challenges of Graduation Internship Perceived by Students Majored in English Studies}

\section{Table 2. Challenges of Graduation Internship Perceived by Students Majored in English Studies}

\begin{tabular}{llllll} 
No. & \multicolumn{1}{c}{$\begin{array}{c}\text { Challenges of the Graduation Internship } \\
\text { (5-point Likert-type scales) } \\
\text { The internship is challenging because: }\end{array}$} & $\begin{array}{c}\text { Mean } \\
(\mathrm{n}=92)\end{array}$ & $\begin{array}{c}\text { Minimu } \\
\mathrm{m}\end{array}$ & $\begin{array}{c}\text { Maximu } \\
\mathrm{m}\end{array}$ & Std. Dev \\
\hline 1 & I do not have sufficient professional knowledge. & 2.88 & 1 & 5 & 1.057 \\
\hline 2 & I do not have sufficient personal skills. & 2.65 & 1 & 5 & 1.104 \\
\hline 3 & The theories learnt do not relate to working tasks. & 2.64 & 1 & 5 & 1.182 \\
\hline 4 & $\begin{array}{l}\text { The connection among the supervisor, the department, and } \\
\text { the company is not strong enough. }\end{array}$ & & 1 & 5 & 1.063 \\
\hline 5 & The assessing method of the internship is inappropriate. & 2.62 & 1 & 5 & .993 \\
\hline
\end{tabular}




\begin{tabular}{|c|c|c|c|c|c|}
\hline 6 & The support from the department is not enough. & 2.52 & 1 & 5 & .943 \\
\hline 7 & $\begin{array}{l}\text { Tasks assigned do not relate to the major learnt at } \\
\text { university. }\end{array}$ & 2.41 & 1 & 5 & 1.131 \\
\hline 8 & I have slow adaptation to the working environment. & 2.33 & 1 & 5 & .962 \\
\hline 9 & I have a lack of confidence and dynamic. & 2.32 & 1 & 5 & 1.026 \\
\hline 10 & $\begin{array}{l}\text { The working time is not sufficient for me to learn from the } \\
\text { job. }\end{array}$ & 2.25 & 1 & 5 & 1.012 \\
\hline 11 & $\begin{array}{l}\text { The company is not respectful and views the intern as a } \\
\text { disposal labor. }\end{array}$ & 2.10 & 1 & 5 & 1.028 \\
\hline 12 & $\begin{array}{l}\text { The relationship with the company's supervisor is not } \\
\text { friendly. }\end{array}$ & 2.09 & 1 & 5 & .847 \\
\hline \multicolumn{2}{|c|}{ Overall mean } & 2.45 & & & 1.029 \\
\hline
\end{tabular}

Table 2 shows the mean scores of the 12 items of internship challenges perceived by the research participants, using a five-point Likert-type scale, ranging from "Strongly disagree" (1) to "Strongly agree" (5) with number 3 representing "Neither disagree nor agree". Overall, students did not feel that the graduation internship was a challenging task with the overall mean score standing at 2.45. From the interns' perspective, the challenging aspect of the internship was mainly their knowledge of the job, and the interns' soft skills. A couple of interviewees expressed that, via the internship program, they understood more about the workplace culture and the tasks they would obtain; however, only a few of them claimed that they improved their professional skills. Several informants indicated that the amount of task was too tough for them. They were expected to take almost the same workload as full-time employees.

Additionally, having to keep the balance between working and writing the final internship report made the interns feel rather exhausted. Most of the supervisors were reported to have a very busy schedule; hence, the support given was not sufficient, especially when interns needed comments on how to improve their performance. With reference to the personal skills, interviewees mostly reported not having adequate problem-solving skills. Giving appropriate solutions to certain problems requires considerable experience. As they had just gradually been entering the workforce, it is understandable that they needed time to enhance this ability. The third highest score was "The theories learnt do not relate to working tasks". After being interviewed, most participants, mainly those majoring in Business English and Corporate Communication confirmed this statement. This was because the main courses students took in their training programme were related to English language studies. They could also take minors in business and corporate communication. However, when doing the internship, they would do tasks related to business and corporate communication fields. This was the reason why they lacked professional knowledge in the fields they worked as interns.

Respondents disagreed the most with the item "The relationship with the company's supervisor is not friendly". After interviewing, the common finding was that interns and their supervisors had either friendly or normal interactions. The second lowest disagreement was "The company is not respectful and views the intern as a disposal labour", which is not a popular disagreement among interviewees (mean $=2.10)$. One informant majored in Interpretation and Translation imparted that:

Being an intern in the field of Interpretation and Translation, my utmost expectation is the company should demonstrate a respect towards their interns. To be honest, some companies offer no compensation but force us to do lots of tasks. In addition, after finishing the tasks given, I need an in-charge person to have them checked. The supervisor does not promptly take my work - whose doer is still a learner - but then blame me if mistakes happen. 
The third lowest mean score item is "The working time is not sufficient for me to learn from the job". The Std. Dev of this variable was 1.012, which indicates that data points are widely spread from the mean (Bryman, 2012). This number showed that students' opinions are rather contradictory. A research participant majoring in English Language Teaching disclosed:

I was assigned lots of classes during the internship. To be specific, I taught about 40 hours per week, which made me extremely exhausted. Furthermore, I had to balance the time to complete my internship report. Additionally, the time needed to prepare the upcoming lessons was very limited, so I was almost always in a hurry. I also had to work during the workdays and at weekends, which took away the relaxation time needed to refresh myself.

Being assigned appropriate tasks, but in an overwhelming amount made the interns became stressed. A student majoring in Corporate Communication revealed that her working time was not fixed. In the morning, she was barely given any tasks. However, tasks were usually delivered in the afternoon, which made her stay up late in the company to finish them.

Data from the interviews exposed two more challenges perceived by the interns writing the final internship report and being assessed by only one university supervisor. That "writing report is challenging" was the most common statement made by the interviewees. Most of interns faced challenges in finalizing and narrowing the topics. They explained that during the 15-week internship, it took them the first few weeks to get used to the position. After having been familiar with the jobs, more tasks were assigned, this meant that time spent in the report was shortened. Furthermore, some interns barely had time to see their supervisors because they had to work at weekends, or simply because their working schedule and that of the supervisors was not matched. Thus, supervisors' guidance was not sufficient. The interns constantly felt suffered when completing the reports. Secondly, being assessed by only one supervisor is problematic. Some interns stated that this was one-sided grade, which accounts for $30 \%$ of the total grade, and was not likely to be objective. This could be affected by the grader's sensibility, which would not exactly reflect the real ability of the interns. In addition, owing to the supervisors' busy agenda, they were not able to give comments to the interns' reports in a precise and prompt manner. For these reasons, many respondents suggested that there should be a committee of the internship supervisors on grading students' performance.

\section{The Necessity of Internship}

Table 3. Regression Analysis Summary Variables Predicting Perceived Internship Necessity

\begin{tabular}{|c|c|c|c|c|c|c|}
\hline Variable & B & \multicolumn{2}{|c|}{$95 \% \mathrm{CI}$} & $\beta$ & $\mathbf{t}$ & $\mathbf{p}$ \\
\hline (Constant) & 2.589 & 1.078 & 4.1 & & 3.412 & 0.001 \\
\hline $\begin{array}{l}\text { Know how to perform vital tasks in the } \\
\text { position }\end{array}$ & 0.214 & -0.002 & 0.43 & 0.229 & 1.973 & 0.052 \\
\hline $\begin{array}{l}\text { Apply academic knowledge on } \\
\text { experiential learning }\end{array}$ & 0.036 & -0.174 & 0.246 & 0.04 & 0.344 & 0.732 \\
\hline $\begin{array}{l}\text { Enhance my English language } \\
\text { proficiency }\end{array}$ & -0.006 & -0.216 & 0.204 & -0.007 & -0.057 & 0.955 \\
\hline $\begin{array}{l}\text { Enhance my skills in computer and } \\
\text { office facility usage }\end{array}$ & -0.033 & -0.231 & 0.166 & -0.035 & -0.327 & 0.745 \\
\hline *Expand my professional knowledge. & -0.259 & -0.478 & -0.04 & -0.277 & -2.357 & 0.021 \\
\hline $\begin{array}{l}\text { Become more mature in terms of } \\
\text { personality. }\end{array}$ & 0.16 & -0.129 & 0.45 & 0.156 & 1.102 & 0.274 \\
\hline
\end{tabular}




\begin{tabular}{lcccccc}
\hline Enhance my communication skills & 0.003 & -0.297 & 0.304 & 0.003 & 0.022 & 0.983 \\
\hline $\begin{array}{l}\text { Become more adaptable to different } \\
\text { circumstances }\end{array}$ & -0.111 & -0.456 & 0.234 & -0.084 & -0.643 & 0.522 \\
\hline Enhance my problem-solving skills & 0.032 & -0.235 & 0.299 & 0.03 & 0.238 & 0.813 \\
\hline Enhance my team work skills & -0.056 & -0.276 & 0.163 & -0.059 & -0.511 & 0.611 \\
\hline Enhance my employability skills & 0.137 & -0.126 & 0.4 & 0.142 & 1.039 & 0.302 \\
\hline *Understand job values & 0.369 & 0.101 & 0.636 & 0.339 & 2.741 & 0.008 \\
\hline *Build my future career plans & -0.343 & -0.581 & -0.106 & -0.341 & -2.88 & 0.005 \\
\hline *Confirm my career aspirations and & 0.327 & 0.092 & 0.563 & 0.353 & 2.766 & 0.007 \\
\hline career goals & -0.014 & -0.241 & 0.213 & -0.016 & -0.12 & 0.905 \\
\hline Expand my working relationship & & & & & & \\
\hline Note: $R^{2}=.349 ; F=2.713 ; * p<.05$ & & & & & & \\
\hline
\end{tabular}

The research participants showed that they highly evaluated the necessity of the internship with the mean score of 4.48 using a five-point Likert-type scale ranging from "Strongly disagree" (1) to "Strongly agree" (5). Standard multiple regression analysis was conducted to explore the correlation between variables of internship benefits and the overall value of internship necessity and to evaluate how well items of internship benefits could significantly predict participants' perception of internship necessity. The results indicated that the model was statistically significant, $F(15,76)=2.713, p<.05$, and explained for 34.9 percent of the variation for the internship necessity $\left(R^{2}=.349\right)$. The analysis shows that, among the variables added, four variables did significantly predict the value of internship necessary. These included "expand my working relationship" (Beta $=-.277, t=-2.357, p<$ $.05)$, "understand job values" (Beta $=.339, t=2.741, p<.05)$, "build my future career plans" (Beta $=-.341, t=-2.88, p<.05)$, and "confirm my career aspirations and career goals" $($ Beta $=.353, t=2.766, p<.05)$. The multiple regression model showed that "confirm my career aspirations and career goals" makes the strongest contribution in explaining the dependent variable when the variance explained by all other variables in the model is controlled. The Beta value for building future career plans, understanding job values, and expanding working relationship were slightly lower.

\section{CONCLUSION}

There was a common agreement in the necessity of internship (Mean $=4.48$ ), overall benefit of the internship (Mean $=4.15$ ), and disagreement in the overall challenge of the internship (Mean $=2.45$ ). Thus, it could be concluded that the graduation internship for students of English study is rather effective. The findings indicate that students perceived personal skills and employment gain as the most beneficial aspects of the internship while professional skills were not highly perceived as beneficial. Interacting with other employees in the real workplace, as well as being given authentic tasks largely enhances students' softskills as well as the ability to retain the position or find job after graduation. Moreover, because of the authenticity and specialization of the working environment and tasks assigned, most interns found there was a loose connection between internship experience and knowledge learnt at school.

In addition, students consider that their internships are challenging due to their professional and personal preparation, together with the university's arrangements. On the other hand, the obstacles originating in the company do not have considerable influence. Qualitative data point out that most students commonly agree that difficulties are challenges to sharpen their skills, and that such obstacles could be easier to solve on conditions of sufficient preparation and efficient cooperation. 
This study can be beneficial to a couple of relevant stakeholders. Students, upon recognizing the values of internship, can make the most of their experience and make full use of internship opportunities to develop their own personal and professional skills. The study is also a good source for academia in re-evaluating its academic curriculum to meets students' needs and add values to employability of their own graduates. The study can also help the businesses to recognize the importance of internship to their own services. By allowing interns to come to their organizations, companies can satisfy the community's expectations of community service. Through internship, employers also have the chance to keep the brightest students to be their full-time employees.

In order to help the interns to make the most of their internship time, some improvement should be made. For the interns, they should better prepare themselves for the internship in terms of academic knowledge and communication skills. In addition, taking initiative and keeping positive viewpoints are also recommended. It is also proposed that prior to sending students to the internship, formal training sessions or a series of workshops to orient students with common potential problems encountered at the workplace as well as the report writing process should be provided. Last but not least, in addition to instant benefits from hosting the internship, effectively organizing the internship could bring sustainability for the companies in the long-term on condition that they periodically reevaluate their internship structure, offering close supervision to interns, and considering such short-term workers as a part of their system.

The current research has several limitations. Concerning the sample size, it could not be generalized for the whole population. This is due to the nature of individual's workplace allocation. Furthermore, the data of the study was collected from one programme of a university, so the results cannot represent interns in general due to its uniqueness. There is also a need to compare students' perception of pre- and post-internship. This is to better assess the internship effectiveness and evaluate the changes of interns' perceptions through internship program. In addition, although the research is about the benefits and difficulties of the internship from the English majored student viewpoints, there is a lack of an in-depth study in each concentration due to the time constrain.

Further studies should focus on the following aspects. Firstly, a longitudinal study is needed to better reflect viewpoints from students of different cohorts, as well as to improve the reliability of the study by enlarging the sample size. Moreover, it is vital to conduct the research before, during, and after the internship to assess the probable changes in their perception. Besides, future researches could explore the differences in the interns' perception of the internship experiences by comparing the demographic variables such as age groups, genders, programmes, universities and so on to evaluate the effectiveness of their curricula and the readiness of their students to enter the workforce.

\section{REFERENCES}

Ahanchian, M., Sharafi, S., Vafaee, M., \& Hajiabadi, F. (2017). Evaluate the effectiveness of internship program in nursing student using Kirkpatrick's model. Research in Medical Education, 9(1), 9-17.

Akella, D. (2010). Learning together: Kolb's experiential theory and its application. Journal of Management \& Organization, 16(1), 100-112.

Anjum, S. (2020). Impact of internship programs on professional and personal development of business students: a case study from Pakistan. Future Business Journal, 6(1), 1-13.

Babbie, E. R. (2015). The practice of social research (14 ${ }^{\text {th }}$ ed.). California: Wadsworth.

Berryman, S. E. (1991). Designing effective learning environments: Cognitive apprenticeship models. New York: Institute on Education and the Economy. 
Bradshaw, C., Tighe, S. M., \& Doody, O. (2018). Midwifery students' experiences of their clinical internship: A qualitative descriptive study. Nurse Education Today, 68, 213217.

Brooks, L., \& Simpson, L. (2014). Experiential learning in higher education: Implications for improving employability of FCS graduates. Preparation and Advancement in the Labor Force, 106(2), 16-21.

Bryman, A. (2012). Social research methods. Oxford: Oxford University Press.

Cannon, J.A., \& Arnold, M.J. (1998). Student expectations of collegiate internship programmes. Journal of Education for Business, 73(4). 202-205.

Coco, M. (2000). Internships: A try before you buy arrangement. SAM Advanced Management Journal, 65(2), 41- 47.

Cohen, L., Manion, L., \& Morrison, K. (2002). Research methods in education. London: Routledge.

Cook, S. J., Parker, R. S., \& Pettijohn, C. E. (2004). The perceptions of interns: A longitudinal case study. Journal of Education for Business, 79(3), 179-185.

Cresswell, J. W. (2012). Educational Research: Planning, conducting, and evaluating quantitative and qualitative research. Boston: Pearson Education, Inc.

De Fruyt, F., Wille, B., \& John, O. P. (2015). Employability in the 21st century: Complex (interactive) problem solving and other essential skills. Industrial and Organizational Psychology, 8(2), 276-281.

Degravel, D. (2011). Internships and small business: A fruitful union. Journal of Management Policy and Practice, 12(2), 27-43.

Di Lorenzo-Aiss, J., \& Mathisen, R. E. (1996). Marketing higher education: Models of marketing internship programs as tools for the recruitment and retention of undergraduate marketing majors. Journal of marketing for higher education, 7(1), 7184.

Divine, R. L., Linrud, J. K., Miller, R. H., \& Wilson, J. H. (2007). Required internship programs in marketing: Benefits, challenges and determinants of fit. Marketing Education Review, 17(2), 45-52.

Dörnyei, Z., \& Csizér, K. (2012). How to design and analyze surveys in second language acquisition research. In A. Mackey \& S. M. Gass (Eds.), Research methods in second language acquisition: A practical guide (First ed., pp. 74-94). Malden, MA: WileyBlackwell.

Duncan, D. W., Birdsong, V., Fuhrman, N., \& Borron, A. (2017). The Impacts of a National Internship Program on Interns' Perceived Leadership, Critical Thinking, and Communication Skills. Journal of Leadership Education, 16(2) 23-39.

Gault, J., Redington, J., \& Schlager, T. (2000). Undergraduate business internships and career success: Are they related. Journal of Marketing Education, 22(1), 45-53.

Gifford, B. R. (2012). Test policy and test performance: Education, language, and culture. Dordrecht: Springer Science \& Business Media.

Glaser, B. G., \& Strauss, A. L. (2009). The discovery of grounded theory: Strategies for qualitative research. New York: Transaction Publishers.

Golinkoff, R. M., \& Hirsh-Pasek, K. (2016). Becoming brilliant: What science tells us about raising successful children. Washington: APA LifeTools. 
He, Y., \& Qin, X. (2017). Students' perceptions of an internship experience in China: A pilot study. American Council on the Teaching of Foreign Languages, 50(1), 57-70.

Henry, L. G., Razzouk, N. Y., \& Hoverland, H. (1988). Accounting internships: A practical framework. Journal of Education for Business, 64(1), 28-31.

Hergert, M. (2009). Student perceptions of the value of internships in business education. American Journal of Business Education, 2(8), 9-14.

Hoover, N. L., O'Shea, L. J., \& Carroll, R. G. (1988). The supervisor-intern relationship and effective interpersonal communication skills. Journal of teacher education, 39(2), 2227.

Hoyle, J., \& Deschaine, M. E. (2016). An interdisciplinary exploration of collegiate internships Requirements for undergraduate and graduate programs. Emerald, 58(4), 372-389.

Ip, I. (2015). Negotiating educated subjectivity: Intern labour and higher education in Hong Kong. TripleC, 13(2), 501-508.

Jackel, D. (2011). Evaluating the effectiveness of an internship program. (Master thesis, Western Kentucky University, 2011). Retrieved from http://digitalcommons.wku.edu/theses/1117

Jackling, B., \& Natoli, R. (2015). Employability skills of international accounting graduates: Internship providers' perspectives. Emerald Insight, 57(7), 757-773.

Jianning, W. A. N. G., \& Lee, M. H. (2019). Based on work value to discuss the effect of college students' corporate internship on the employability. Revista de Cercetare si Interventie Sociala, 64, 25-36.

Kasli, M., \& Ilban, M. O. (2013). The relationship between problems faced during internships and interns' view of profession and intention to work in the tourism industry. Egitim Arastirmalari-Eurasian Journal of Educational Research, 52, 79-96.

Kolb, D. A. (1984). Experiential learning: Experience as the source of learning and development. England: Pearson Education Limited.

Kuh, G. D. (2008). Excerpt from high-impact educational practices: What they are, who has access to them, and why they matter. Association of American Colleges and Universities, 14(3), 28-29.

Leeder, S. R. (2007). Preparing interns for practice in the 21st century. Medical journal of Australia, 186(S7), S6-S8.

Lodico, M.G., Spaulding, D.T., \& Voegtle, K.H. (2006). Methods in educational research from theory to practice. San Francisco: John Wiley \& Sons.

Maelah, R., Mohamed, Z. M., Ramli, R., \& Aman, A. (2014). Internship for accounting undergraduates: Comparative insights from stakeholders. Education+ Training. 56(6), 482-502.

Ministry of Education and Training. (1962). Internship law for university students and college students. Hanoi: Vietnam Government.

Moghaddam, J. M. (2011). Perceived effectiveness of business internships: Student expectations, experiences, and personality traits. International Journal of Management, 28(4), 287-303.

Moran, T. J. (2013). Study of interns' perception of and satisfaction with experiential learning (Doctoral dissertation, Northern Illinois University, 2013). Retrieved from 
https://search.proquest.com/openview/6123a0ce05953d9504b780ca1337407b/1?pqorigsite $=$ gscholar $\& \mathrm{cbl}=18750 \&$ diss $=\mathrm{y}$

Muijs, D. (2010). Doing quantitative research in education with SPSS (2 $2^{\text {nd }}$ ed.). London: Sage.

Neuman, W.L. (2014). Social research methods: Qualitative and quantitative approaches (7th ed.). United States of America: Pearson.

Nevett, T. (1985). Work experience: The essential ingredient in British programs. Journal of Marketing Education, 7, 13-18.

Nicholas, A. J. (2016). Internships: Experiential learning, academic connection and assessment. Faculty and Staff - Articles \& Papers, 61.

Novotorov, A. V. (2001). Perceived impact of internship and practical training programs on professional and personal growth: Implications to agricultural and extension education. (Doctoral dissertations, Iowa State University, 2001). Retrieved from http://lib.dr.iastate.edu/rtd/1069

Pallant, J. (2013). SPSS survival manual: A step by step guide to data analysis using SPSS for Windows. Oxford: Oxford University Press.

Patton, L., \& Dial, F. (2000). Testing the water: A survey on HRD internships. Training \& Development Journal, 42(10), 48-50.

Pennington, G. (2013). Soft skills in the business and personal world. EFMD Global Focus, $7(3), 52-55$.

Renganathan, S., Karim, Z. A. B. A., \& Li, C. S. (2011). Students' perception of industrial internship programme. Journal of Education \& Training, 54(2/3), 180-191.

Ross, L. E., \& Elechi, O. O. (2006). Student attitudes towards internship experiences: From theory to practice. Journal of Criminal Justice Education, 13(2), 297-312.

Ryff, C., \& Singer, B. (1996). Psychological well-being: Meaning, measurement, and implications for psychotherapy research. Psychotherapy and psychosomatics, 65, 1423.

Santrock, J. W. (2011). Educational psychology. New York: MsGraw-Hill.

Scholz, R. W., Steiner, R., \& Hansmann, R. (2004). Role of internship in higher education in environmental sciences. Journal of Research in Science Teaching: The Official Journal of the National Association for Research in Science Teaching, 41(1), 24-46.

Scott, M. E. (1992). Internships add value to college recruitment. Personnel Journal, 71(4). 59-63.

Sides, C. H., \& Mrvica, A. (2007). Internships: Theory and practice. New York: Routledge.

Spann, T. (1994). The internship coordinator: Problems and perils. Paper presented at the Annual Meeting of the Speech Communication Association. New Orleans, LA.

Stichman, A. J., \& Farkas, M. A. (2005). The pedagogical use of internships in criminal justice programs: A nationwide study. Journal of Criminal Justice Education, 16(1), 145-179.

Taylor, S. M. (1988). Effects of internships on individual participants. Journal of Applied Psychology, 73(3), 393-401.

Thiel, F. R., \& Hartley, N. T. (1997). Cooperative education: A natural synergy between business and academia. Advanced Management Journal, 62(3), 19-24. 
Tran, L. H. N. (2019). Building soft skills for employability: Challenges and practices in Vietnam. London: Routledge.

Tran, T. L. H. \& Duyen, N. T. M. (2018). Internship-related learning outcomes and their influential factors. Education+ Training.

Truong, H. T., Laura, R. S., \& Shaw, K. (2016). New insights for soft skills development in Vietnamese business schools: Defining essential soft skills for maximizing graduates' career success. International Journal of Industrial and Systems Engineering, 10(6), 1857-1863.

Vo, H. P., Berglund, A., \& Daniels, M. (2017, April). A perspective from Vietnamese students on teaching of soft skills. In 2017 International Conference on Learning and Teaching in Computing and Engineering (LaTICE) (pp. 23-24). Hong Kong: IEEE.

Yassin, A. A., Abdul Razak, N., Qasem, Y. A., \& Saeed Mohammed, M. A. (2020). Intercultural Learning Challenges Affecting International Students' Sustainable Learning in Malaysian Higher Education Institutions. Sustainability, 12(18), 7490.

\section{AUTHORS' BIO}

Tran Ngoc Tien, Ph. D., is a university instructor of the Department of English Language Studies, Hoa Sen University, Vietnam. He graduated from Ritsumeikan Asia Pacific University (Japan), Edith Cowan University (Australia); and has more than 15 years of teaching at various levels. He has published a couple of papers in Japan, America and England and joined numerous conferences worldwide. His interests of researching are educational attainment, job satisfaction, learning motivation, English language learning and teaching.

Vu Thi Quynh Trang was a former student of English Language Studies, Hoa Sen University, Vietnam. She is currently doing her master's program at School of Education and Professional Development, University of Huddersfield, Huddersfield, United Kingdom. Her research interests include second language learning and teaching, educational policies, and teaching English in different contexts. 